\title{
ADOLESCENTS' HEALTH BEHAVIOUR ACCORDING TO SPORT AND FAMILY STRUCTURE ${ }^{2}$
}

\author{
Authors: \\ Karolina Eszter Kovács \\ University of Debrecen \\ Beáta Erika Nagy \\ University of Debrecen
}

\author{
Lectors: \\ Tamás Józsa \\ University of Debrecen \\ Barnabás Szilágyi \\ University of Debrecen \\ Ferenc Mező \\ Eszterházy Károly University \\ Edina Szabó
}

E-mail address of the first author:

karolina92.kovacs@gmail.com

Kovács, Karolina Eszter and Nagy, Beáta Erika (2017): Adolescents' health behaviour according to sport and family structure. Különleges Bánásmód, III. évf. 2017/1. szám, 27-37. DOI 10.18458/KB.2017.1.27

\begin{abstract}
Health awareness plays an important role in our life. It's important to live an appropriate lifestyle because adequate way of life helps to conserve the optimal health status and to prevent chronic diseases (Conner, 2005). The role of the family and parents is still significant. Children turn toward their peers but the family stands in the background as a supporting basis (Kovács \& Pikó, 2009). However this function cannot be fulfilled with the crisis and disintegration of family structure which can mean a serious stressor, so it can increase the appearance and in serious case the longlasting subsistence of harmful health behaviour (Bramlett \& Blumber, 2007). The aim of the study is to measure the appearance of smoking, getting drunk and substance use depending on sport and family structure in three counties on the basis of FASCES 2015. According to the results only pursuing sport does not influence the testing rate but it can be seen as a protective factor. Family structure considered on its own is not a significantly influencing factor but the mediating role of social factors are well perceptible in case of smoking, getting drunk and using weed.
\end{abstract}

Keywords: adolescence, sport, family, health-risk behaviour

Disciplines: educational science, psychology

\footnotetext{
${ }^{2}$ The editorial board does not take any responsibilty for the English of the papers. Indeed, we made some slight changes but wanted to keep the style of the authors.
} 


\section{Absztrakt}

$\mathrm{Az}$ egészségtudatos életvitel meghatározó tényező egészségi állapotunk tekintetében, kiemelkedő szereppel bír az optimális egészségi állapot megőrzésében és a krónikus betegségek megelőzésében egyaránt (Conner, 2005). A család és a szülők szerepe még jelentős; a gyermekek egyre inkább kortársaik felé nyitnak, ám a család támogató bázisként ott matad a háttérben (Kovács \& Pikó, 2009). Ugyanakkor a családban bekövetkező krízis okán nem tud teljesülni ez a funkció, s komoly stressz forrást jelent a fiatal számára, növelve az egészségkárosító magatartásformák kipróbálásának vagy akár hosszú távú fennmaradásának esélyét (Bramlett \& Blumber, 2007). Kutatásunk célja a dohányzás, lerészegedés, valamint illegális szerhasználat kipróbálását, valamint a sportolást vizsgáljuk meg 10. osztályos tanulók körében három megyében, a FASCES-OKM 2015 alapján.

Az eredmények alapján a sportolás önmagában nincs jelentős hatással a vizsgált változókra, ugyanakkor protektív tényezőként tekithető. A családszerkezet sem számít szignifikánsan befolyásoló tényezőnek önmagában véve, ugyanakkor a társas faktorok mediáló szerepe jól látható a dohányzásban, alkoholfogyasztásban és füvezésben egyaránt.

Kulcsszavak: Serdülőkorúak, sport, család, egészségkárosodás

Diszciplína: neveléstudomány, pszichológia

\section{RISK-TAKING IN ADOLESCENCE}

Regarding health-risk behaviours, adolescence is the most risky period as the frequency of these is growing while the health protecting behaviour is decreasing (Lohaus et al, 2009). The common characteristic of different kind of risky behaviours (e. g. alcohol consumption, substance use, smoking or promiscuity) is that young people think on these as an adult thing which makes them attractive.

Some kind of risk-taking and health-risk behaviours have positive effects in short-term as alcohol consumption, substance use or smoking can have a relaxing effect, reduce temporarily anxiety and entails with peasant mood. The high prevalence of harmful habits can be caused by these facts which can be a huge motivator in adolescence as well. Thus one aspect of risktaking is the discretion whether it is worth the short-term enjoyment namely the health awareness is in connection with future orientation (Rothspan \& Read, 1996). The choice of actual advantages is typical in this life period, ignoring the long-term health advantages (Goldberg et al, 2002). Otherwise, the tryout is not necessarily maladaptive in adolescence as health-risk behaviour can be one source of psychosocial development which has a health protective function: integration to peer groups, rebellion against the authority or compensation (Brassai, 2010). In this meaning, this cannot be regarded obviously harmful in psychological aspect if the adolescent experience the short-term advantages. It means a problem when the health-damaging behaviour endures for long.

The results of the researches on young people's health behaviour are getting more worrisome year by year: the usage of harmful habits and regular sexuality is beginning earlier and has a broader scope (Csizmadia \& Várnai 2003; Németh 2003; Sebestyén 2003) and the prevalence of psychosomatic symptoms is abnormally high among young people (Susánszky \& Szántó 2002).

One of the biggest sources of danger is smoking; the rate of smoking is really high in domestic population. It can be said according to the results of HBSC (Health Behaviour in School-aged children) in 2010, that the prevalence of the tryout of smoking is higher with the age. $14,5 \%$ of children in the $5^{\text {th }}$ class said that they have ever tried out smoking while $76,8 \%$ of them have tried it out in $11^{\text {th }}$ class. It is more likely for boys in every age bracket but the 
rate almost will be compensated in secondary level (Németh \& Költö, 2011). Unfortunately, the rate of regular smokers (at least in every week) is growing with the age. In $5^{\text {th }}$ class, 3,5\% of boys and $1 \%$ of girls said that they are regular smokers but in $7^{\text {th }}$ class the rate was $8,8 \%$ among boys and $6,7 \%$ among girls. After this a sharp increase can be seen as in $9^{\text {th }}$ class $29,6 \%$ of boys and $26 \%$ of girls while in $11^{\text {th }}$ class $41,5 \%$ of boys and $33,8 \%$ of girls can be regarded as regular smokers (Németh \& Költö, 2011).

Beside smoking, alcohol consumption is also a huge problem; according to the results of HBSC, trying out alcohol often happens early. $30 \%$ of children in the $5^{\text {th }}$ class have ever consumed alcohol namely $44 \%$ of boys and $30,5 \%$ of girls. The difference in the tryout of alcohol among boys and girls is significant in primary school however this difference disappears in secondary school. In the $9^{\text {th }}$ class, $86,3 \%$ of boys and $83,9 \%$ of girls said that they have ever consumed alcohol while in the $11^{\text {th }}$ class the rate is $91,3 \%$ among boys and $90,6 \%$ among girls. It can be said regarding the consumption frequency that the rate of consumption is significantly higher among older children (Németh \& Költő, 2011).

Illegal substance use needs to be mentioned among harmful habits. In Hungary, the results of drug consumption are worrisome as well. HBSC in 2010 showed that almost one third of children in $9^{\text {th }}$ and $11^{\text {th }}$ class have ever tried out some kind of illegal substance, medicine as misuse or some kind of inhalant. The rate of trying out is higher among boys as $29,7 \%$ of boys while $22,3 \%$ of girls have tried it out at $t$ least once in $9^{\text {th }}$ class and the rate is $38,4 \%$ among boys and $31,2 \%$ among girls in the $11^{\text {th }}$ class. Regarding drug consumption, the most frequency of trying out cannabis 1 or 2 times $(8 \%)$ as well as taking in medicines with alcohol $(7,2 \%)$ or alone $(3,4 \%)$ and amphetamines (speed) $(4,7 \%)$ showed the highest prevalence (Németh \& Költő, 2011).

\section{Sport and risky behaviour}

Unfortunately, the measure of regular physical activity is low in west societies however the positive effects of sport are well-known. The research of Hallal et al (2012, quote Smith et al., $2015)$ showed that approximately one third of adults $(31,1 \%)$ in physically inactive among adults (over 15 years old people) in 122 countries. This is a huge problem regarding sport -as in previous summary also can be seen- has several benefits. It was claimed too that active children will become significantly healthier and wealthier compared with inactive ones (Stevenson, 2010). It is important to learn habits of healthy lifestyle as early behaviour patterns are good predictors of latter behaviour (Ajzen, 2011, quote van Bree et al., 2015). Almost half of the Hungarian population sits or stands during the work (involving other activities as work beside the workplace e. g. housework, learning etc.). Only 4,5\% of the population does exercise every day while $67 \%$ of them does not pursue sport 10 minutes per day at all (ELEF, 2014).

According to national and international investigations, it can be said that physically active adolescents are more satisfied with their life and have less depressive symptoms compared with inactive ones (Pluhár és mts., 2004, idézi Pikó és Keresztes, 2007). Otherwise, those who pursue sport regularly (both on amateur and competitive level) feel healthier, are more resilient (Kovács, 2014) and are more satisfied with themselves (Kovács és Perényi, 2014).

The results of the researches on risky behaviours are ambivalent. One group of the investigations says that active young people have healthier nutrition and the risk of obesity is lower (Pate és mts, 1996; Steptoe és mts, 1997), live a more safety sexual life (Sabo és mts, 1999). They also have better mood compared with inactive people and the attribute themselves a better fitness and health status thus sporty behaviour parallels with better life quality (Pluhár és mts, 2004). In case of smoking, sport is a protective factor as the amount of smoking is lower among athletes (Burke és mts, 1997). However, there are other research results as well which showed a positive relation between sport and health-damaging 
behaviour including smoking, alcohol and drug consumption and promiscuity) (Faurie és mts, 2004). This is typical for competitive athletes first of all where the child would like to reduce the stress caused by the big pressure and achievement compulsion in some kind of way or it would like to improve its achievement. According to some researches, competitive athletes consume more alcohol and begin it earlier (Hildebrand és mts, 2001) therefore the emphasise need to be put on physical activity done by an appropriate way.

\section{The role of family in health-risk behaviour}

The role of family is indisputable in forming the adolescent's healthy and risky behaviour and health awareness (Pikó, 2005). This is the first social atmosphere which is a pattern for the child not only in childhood but in adulthood as well. Peer relationships are getting more and more important but family stands in the background as a support basis (Kovács és Pikó, 2009).

Family has different kind of protective role in regard of adolescents' health behaviour. More researches have investigated the effect of leisure time activities in connection of the parents which functions as a protective factor for the values and health awareness of the child (Brassai és Pikó, 2005). Those adolescents whose parents paid attention and controlled the leisure time activities of their children more consumed alcohol or drug less likely (Ford, 2009, Järvinen és Østergard, 2009, idézi Kovács és Pikó, 2009). Therefore, structural crisis in the family means a huge risk.

The forming of the family structure influences the individual's relation to its family, the strength of the relationship, the socialisation, the sense of security and social support as well (Kopp és Skrabski, 2001; Poortinga, 2006). Researches claim that changes in the structure of the family have a negative effect on health-conscious behaviour as the prevalence of risky and health-damaging behaviour is higher among children from non-intact families. The physiological and emotional development of children from single-parent families is worse and they commit in risky behaviours more (Bramlett és Blumber, 2007). The substance use is higher among these children (Barrett és mts, 2006; McArdle és mts, 2002) and the prevalence of early sexual experiences and pregnancy in adolescence is higher too (Bonnel és mts, 2006). The likelihood of smoking is the lowest in traditional two-parent families while among children from patchwork families is the highest (Griesbach, 2003). Pikó claims according to her research called "Youth investigation in the South Great Plain" that non-intact family structure has a negative influence on health-conscious behaviour as it is a risk factor; the appearance of psychosomatic and depression symptoms and the substance use is higher among children from these families. Hair et al (2009) explained that low-risk individuals which means the people who abstain from health-damaging and risky behaviour and are engaged in healthy behaviours comes mostly from traditional families.

Kovács and Pikó (2009) investigated the effect of family structure on health behaviour, smoking, alcohol and marihuana consumption among secondary grammar school students in Szeged. Their results showed that a significant difference can be shown according to the parents' family status as the prevalence of smoking was significantly lower among children from two-parent families while it was higher among children with structural crisis behind them. Common family meals have a positive effect on children's and adolescents' mental health although the amount of these reduces or disappears in case of a structural crisis (Compan és mts, 2002).

\section{The introduction of the investigation}

The aim of the investigation is to measure the different types of risky behaviours and the influential factors of the try-outs including family structure, sport and societal factors. The 
basis of the research was the FASCES 2015 database including 627 students from the $10^{\text {th }}$ class from Borsod-Abaúj-Zemplén, Szabolcs-Szatmár-Bereg and Hajdú-Bihar counties.

First we measured the differences between the differences according to the family structure. The results can be seen in Table 1 .

Table 1: The try-out of the different kind of health-risk behaviours in regard of family structure (person, percent) (Source: FASCES 2015)

\begin{tabular}{|c|c|c|c|c|c|c|c|c|c|c|c|}
\hline & & \multicolumn{2}{|c|}{ Smoking } & \multicolumn{2}{|c|}{$\begin{array}{c}\text { Getting } \\
\text { drunk }\end{array}$} & \multicolumn{2}{|c|}{ Weed } & \multicolumn{2}{|c|}{ Light drug } & \multicolumn{2}{|c|}{$\begin{array}{l}\text { Hard } \\
\text { drug }\end{array}$} \\
\hline & & Yes & $\mathrm{No}$ & Yes & $\mathrm{No}$ & Yes & No & Yes & $\mathrm{No}$ & Yes & $\mathrm{No}$ \\
\hline \multirow{2}{*}{$\begin{array}{l}\text { Traditional } \\
\text { family }\end{array}$} & $\mathrm{N}$ & 302 & 156 & 260 & 197 & & 393 & 25 & 432 & 0 & 446 \\
\hline & $\%$ & 65,9 & 34,1 & 56,9 & 43,1 & 14,0 & 86,0 & 5,5 & 94,5 & 2,0 & 98,0 \\
\hline \multirow{2}{*}{$\begin{array}{c}\text { Single-parent } \\
\text { family }\end{array}$} & $\mathrm{N}$ & 54 & 23 & 52 & 25 & 11 & 65 & 8 & 69 & 6 & 71 \\
\hline & $\%$ & 70,1 & 29,9 & 67,5 & 32,5 & 14,5 & 85,5 & 10,4 & 89,6 & 7,8 & 92,2 \\
\hline \multirow{2}{*}{$\begin{array}{c}\text { Restructured } \\
\text { family }\end{array}$} & $\mathrm{N}$ & 13 & 48 & 37 & 22 & 11 & 50 & 5 & 56 & 2 & 58 \\
\hline & $\%$ & 8,7 & 21,3 & 62,7 & 37,3 & 18,0 & 82,0 & 8,2 & 91,8 & 3,3 & 6,7 \\
\hline
\end{tabular}

According to the results of the One-way ANOVA it can be said that the try-out rate is the lowest among children from traditional family. These results show the holding function of the family and they also prove the fact that the safety family atmosphere is a protective factor against risky behaviours. According to the results, the try-out of getting drunk $(p=0,175)$, light drugs $(p=0,219)$ and hard drugs $(p=0,018)$ is the highest among children from single-parent families while the try-out of smoking $(p=0,121)$ and smoking weeds $(p=0,703)$ was the highest among children from restructured families. The differences were not significant only in case of hard drugs nevertheless they are awareness-raising as they show the tendency that the appearance of health-damaging behaviours is higher among children in whose family a structural crisis happened which means that these children are in more endangered situation compared with their peers from traditional families.

In the investigation, logistic regression analysis was used to measure what kind of factors influence the try-out of smoking, getting drunk and illegal substances (weed, light and hard drug). The factors involved into the investigation were classified into three groups namely family structure, pursuing sport and societal factors. Societal factors were gender, type of settlement (city/town or village), subjective financial status (under or over the average) and employment status of the parents'. The reference group was the group of children from traditional family as the try-out prevalence was the lowest among these children.

\section{Smoking}

In case of smoking it can be said that family structure the family structure itself does not have a significant effect on the smoking try-out and sport does not have a significant influence too. From the involved socio-demographical factors, gender, type of settlement and employment status of the parents didn't show a significant influence. However, subjective financial background shows a significant impact $(p=0,035)$ : those who have better financial background are more likely to try out smoking. Involving these social factors we can see that a significant effect is shown in living in restructured family: those who have this kind of crisis have a 2 times bigger chance to try-out smoking. The results of regression analysis can be seen in Table 2. 
Table 2: The results of logistic regression analysis on the try-out of smoking. (Source: FASCES $2015(N=614))$

\begin{tabular}{|l|r|r|r|}
\cline { 2 - 4 } \multicolumn{1}{c|}{} & Model 1 (ExpB) & Model 2 (ExpB) & \multicolumn{1}{c|}{ Model 3 (ExpB) } \\
\hline Single parent family & 1,213 & 1,200 & 1,536 \\
\hline Restructured family & 1,929 & 1,931 & $2,056^{*}$ \\
\hline Sport & & 0,865 & 0,892 \\
\hline Gender & & & 0,980 \\
\hline Financial background & & & $1,537^{*}$ \\
\hline Type of settlement & & & 0,893 \\
\hline Father's employment & & & 1,724 \\
\hline Mother's employment & & & 0,957 \\
\hline Constant & $1,987^{* * * *}$ & $2,032^{* * *}$ & 1,185 \\
\hline
\end{tabular}

${ }^{*} \mathrm{p}<0,05,{ }^{* *} \mathrm{p}<0,01, * * * \mathrm{p}<0,001$

Family structure and financial status influence the likelihood of smoking together. In case of financial status under the average, the try-out rate is lower among children from traditional families compared with their peers from families with some kind of family structure but in case of financial status over the average, the try-out rate is higher among children from traditional families. That is to say that the financial status under the average means a risk factor for children in non-intact families while the financial status over the average is a risk factor for children in traditional families. It can be said that the change in family structure improve the odds of the smoking try-out.

\section{Getting drunk}

In relation of alcohol consumption, we investigated the prevalence of the try-out of getting drunk. We also could say that neither family structure nor sport has a significant effect however socio-demographical factors have again a significant impact. It can be seen that gender $(p=0,001)$, type of settlement $(p=0,020)$, subjective financial status $(p=0,013)$ and the employment status of the father $(\mathrm{p}=0,022)$ had a significant effect on the try-out). The results of the logistic regression analysis can be seen in the Table 3 .

Regarding gender the appearance of getting drunk seemed to higher which means that males have higher likelihood to try out getting drunk which correlates to previous national and international results. With the involvement of gender, the differences according to the family structure were significant as well: the chance of getting drunk was significantly higher among boys from single-parent families $(75,8 \%)$ compared with the other groups (among boys from traditional families $66 \%$ and from restructured families $64,3 \%$ ). This is to say that children from single-parent families are in more endangered situation, even compared with peers from restructured families.

According to subjective financial status, it could be seen significant differences as well $(p=0,013)$. We can say that children who judge their financial background over the average have tried out getting drunk in higher prevalence $(66,8 \%)$ compared with their peers who judge their financial background under the average. This means that children living in better financial background are more endangered. 
Otherwise, the type of settlement also had a significant effect as the prevalence of trying out getting drunk was higher among adolescents who live in a village $(p=0,020)$ in all family types which means that children living in a village are more endangered.

Table 3: The results of logistic regression analysis on the try-out of getting drunk. (Source: FASCES 2015 (N=614))

\begin{tabular}{|l|r|r|r|}
\cline { 2 - 4 } \multicolumn{1}{c|}{} & Model 1 (ExpB) & Model 2 (ExpB) & \multicolumn{1}{c|}{ Model 3 (ExpB) } \\
\hline Single parent family & 1,512 & 1,502 & $2,145^{* * *}$ \\
\hline Restructured family & 1,360 & 1,362 & 1,746 \\
\hline Sport & & 0,916 & 0,854 \\
\hline Gender & & & $1,796^{* * *}$ \\
\hline Financial background & & & $0,651^{*}$ \\
\hline Type of settlement & & & $1,619^{*}$ \\
\hline Father's employment & & & $1,964^{*}$ \\
\hline Mother's employment & $1,323^{* * *}$ & $1,341^{* * *}$ & 1,457 \\
\hline Constant & & & 0,460 \\
\hline
\end{tabular}

${ }^{*} \mathrm{p}<0,05, * * \mathrm{p}<0,01, * * * \mathrm{p}<0,001$

Las but not at least, the effect of father's employment can be detected as a significant influential factor $(\mathrm{p}=0,022)$ as those whose father or stepfather works are more likely to try out this kind of risk-taking $(59,8 \%)$ compared with those whose father or stepfather does not work $(46,9 \%)$. This result shows that the unemployment of the father is a retentive factor.

In this model we also could see that with the involvement of socio-demographical factors the effect of living in a single parent family appeared as well as those who live in this type of family have a 2 times bigger chance to try out getting drunk.

\section{Smoking weeds}

The logistic regression analysis of trying out weeds showed similar results as it could be seen in case smoking. It can be said too that that neither family structure nor sport shows an obviously significant effect on the likelihood of trying out weeds, however, a tendency could be seen that the try-out rate is higher among children with a structural crisis (firstly in case of restructured families). The financial status showed a significant impact from the involved demographical variables as the values of both the children from single-parent families and restructured families deviate from the values of the children from traditional families but no obvious tendency can be detected in the background. The results of the logistic regression analysis can be seen in Table 4 .

\section{Light drugs}

In case of light drugs it can be said that neither family structure nor sport has a significant effect on the likelihood of the try-out. Furthermore, according to the results of the logistic regression analysis (Table 5) it can be said that any of involved demographical factors have a significant effect on the try-out of light drugs. 
Table 4: The results of logistic regression analysis on the try-out of smoking weeds. (Source: FASCES $2015(N=614))$

\begin{tabular}{|l|l|l|l|}
\cline { 2 - 4 } \multicolumn{1}{c|}{} & Model 1 (ExpB) & Model 2 (ExpB) & Model 3 (ExpB) \\
\hline Single parent family & 1,042 & 1,069 & 1,334 \\
\hline Restructured family & 1,397 & 0,397 & 1,441 \\
\hline Sport & & 1,320 & 1,353 \\
\hline Gender & & & 0,919 \\
\hline Financial background & & & 0,610 \\
\hline Type of settlement & & & $1,153^{*}$ \\
\hline Father's employment & & & 2,091 \\
\hline Mother's employment & & & 0,784 \\
\hline Constant & $0,168^{* * *}$ & $0,160^{* * *}$ & $0,126^{* * *}$ \\
\hline
\end{tabular}

$* \mathrm{p}<0,05, * * \mathrm{p}<0,01, * * * \mathrm{p}<0,001$

Table 5: The results of logistic regression analysis on the try-out of light drugs. (Source: FASCES $2015(N=614))$

\begin{tabular}{|l|l|l|l|}
\cline { 2 - 4 } \multicolumn{1}{c|}{} & Model 1 (ExpB) & Model 2 (ExpB) & Model 3 (ExpB) \\
\hline Single parent family & 1,961 & 1,917 & 1,852 \\
\hline Restructured family & 1,549 & 1,551 & 1,436 \\
\hline Sport & & 0,698 & 0,724 \\
\hline Gender & & & 0,678 \\
\hline Financial background & & & 0,767 \\
\hline Type of settlement & & & 0,985 \\
\hline Father's employment & & & 0,829 \\
\hline Mother's employment & & & 0,817 \\
\hline Constant & $0,061 * * *$ & $0,064 * * *$ & $0,121 * * *$ \\
\hline
\end{tabular}

${ }^{*} \mathrm{p}<0,05, * * \mathrm{p}<0,01, * * * \mathrm{p}<0,001$

\section{Hard drugs}

In case of hard drugs it can be said that the effect of family structure is significant as it was said previously too. This result was confirmed by the logistic regression analysis as well as the try-out rate was much higher among adolescents from single-parent families $(p=0,035)$. Nonetheless, neither sport nor the involved socio-demographical factors have a significant effect on the try-out of hard drugs. The results of the logistic regression analysis can be regarded in the following table. 
Table 6: The results of logistic regression analysis on the try-out of light drugs. (Source: FASCES $2015(N=614))$

\begin{tabular}{|l|r|r|r|}
\cline { 2 - 4 } \multicolumn{1}{c|}{} & Model 1 (ExpB) & Model 2 (ExpB) & \multicolumn{1}{c|}{ Model 3 (ExpB) } \\
\hline Single parent family & $3,478^{*}$ & $3,421^{*}$ & $3,374^{*}$ \\
\hline Restructured family & 1,455 & 1,456 & 1,328 \\
\hline Sport & & 0,739 & 0,808 \\
\hline Gender & & & 0,695 \\
\hline Financial background & & & 0,544 \\
\hline Type of settlement & & & 1,116 \\
\hline Father's employment & & & 0,774 \\
\hline Mother's employment & & & 0,563 \\
\hline Constant & $0,025^{* * *}$ & $0,026^{* * *}$ & $0,077^{* * *}$ \\
\hline
\end{tabular}

${ }^{*} \mathrm{p}<0,05, * * \mathrm{p}<0,01, * * * \mathrm{p}<0,001$

\section{SUMMARY}

In case of the different kind of health-damaging behaviours it can be said according to the logistic regression analysis that sport on itself does not influence significantly the try-outs however its protective role appears as a tendency. Furthermore, family structure on itself is not a significantly influential factor except the try-out of hard drug as in this case a significant difference can be seen because the prevalence of trying out hard drug is significantly higher among children from single-parent families. The values of children from single-parent families and restructured families are worse in comparison with their peers living in traditional families which result shows the importance of the stability and holding force of the family well. Furthermore, it is important to remark the difficulties of restructured families. Although, in this case there are two parents and the financial and emotional support comes from two sides, the presence of health-risk behaviours is higher as the change of the original family model means a serious stress source for the child.

The effect of the societal factors could be detected; the differences in health-risk behaviour according to the family structure could be seen by the involvement of these demographical variables in many cases as it is known that these factors are not independent from each other (e. g. the socio-economic status of families with a structural crisis is worse). These factors are subjective financial status, gender, type of settlement and the employment status of the father.

The results draw the attention to the effect of the structural crisis of the family and to the importance of the role of sport. The role of school is important in the treatment of the problems caused by a divorce (or other crisis) where the adolescent spends large part of its day. Intervention is necessary when deviant behaviour (health-damaging or other behavioural disorder) can be experienced by the adolescent. It is the pedagogues' (firstly the class teacher's) challenge to percept the problem, to keep contact with the parent(s), to turn empathetically to the adolescent and to ask the support of the specialist (e. g. school psychologist) if it is necessary. However, beside the intervention the role of prevention is big too with which the prevalence of risky behaviours can be retreated.

\section{REFERENCES}

Barrett, A. E.\& Turner, J. (2006). Family structure and substance use problems in adolescence and early adulthood: examining explanations for the raltionship. Addiction, 101,109-120. 
Bonnel, C., Allen, E. \& Strange, V. (2006): Influence of family type and parenting behaviours on teenage sexual behaviour and conceptions. (Web: http://jech.bmj.com/) 60,502-506.

Bramlett, M. D. \& Blumsberg, S. J. (2007): Family structure and children's physical and mental health. Health Affairs, 26 (2). 549-558.

Brassai, L. (2010): Válasz a kockázati társadalomra: az élet értelmességébe vetett hit. T3 Kiadó, Sepsziszentgyörgy.

Brassai, L. \& Pikó, B. (2005): Szerhasználat és családi tényezők viszonya középiskolásoknál. Addictologica Hungarica, 4 (1),7-29.

Burke, V., Milligan, R.A.K., Beilin, L.J., Dunbar, D., Spencer, M., Balde, E. \& Gracey, M.P. (1997): Clustering of health-related behaviors among 18-year-old Australians. Preventive Medicine, 26, 724-733.

Compan, E., Moreno, J. \& Ruiz, M. T. (2002): Doing things together: adolescents health and family rituals. (Download: 2016.02.01.). (Web: http://jech.bmj.com/) 56, 89-94.

Conner, M. (2005): Health behaviours. (Download: 2016.02.01.). (Web: http://userpage.fuberlin.de/ schuez/folien/conner2002.pdf).

Csizmadia P.\& Várnai D. (2003): Dohányzás és alkoholfogyasztás. In Aszmann A. (szerk.): HBSC Iskoláskorú gyermekek egészségmagatartása. Országos Gyermekegészségügyi Intézet, Budapest, 49-60.

ELEF (2014): Európai lakossági felmérés, 2014. Statisztikai tükör 2015/29,1-9.

Faurie, C., Pontier, D.\& Raymond, M. (2004) Student athletes claim to have more sexual partners than other students. Evolution and Human Behavior, 25, 1-8.

Ford J. A. (2009): Nonmedical prescription drug use among adolescents: The infl uence of bonds to family and school. Youth \& Society, 40, 336-352.

Goldberg, J. H., Halpern-Felsher, B. L. \& Millstein, S. G. (2002): Beyond invulnerability: The importance of benefits in adolescents' decision $\mathrm{t}$ odrink alcohol. Developmental Psychology, 6, 415-428.

Griesbach, D., Amos, A. \& Currie, C. (2003): Adolescent smoking and family structure in Europe. Social Science and Medicine 56,41-52.

Hair, E. C., Park, M. J. \& Ling, T. J. (2009): Risky behaviors in late adolascence: cooccurence, predictors and concesquences. Journal of Adolescence Health, 45, 253-261.

Hallal, P.C., Andersen, L.B., Bull, F.C., Guthold, R., Haskell, W. \& Ekelund, U.(2012): Global physical activity levels: surveillance progress, pitfalls, and prospects. Lancet, 380, 247-257.

Hildebrand, K.M., Johnson, D.J.\& Bogle, K. (2001) Comparison of patterns of tobacco use between high school and college athletes and non-athletes. American Journal of Health Education, 32, 75-80.

Järvinen, M. \& Østergard, J. (2009). Governing adolescent drinking. Youth \& Society, 40 (3), 377-402.

Kopp M.\& Skrabski Á. (2001). Magatartás és család. Magyar Bioetikai Szemle, 7 (4), 1-25.

Kovács E. \& Pikó B. (2009): A család egészségvédő hatása serdülők körében. Mentálhigiéné és Pszichoszomatika, 10 (4),223.237.

Kovács K. (2014). Kapocs,2, 2-13. (Download: 2016.02.01.). (Web: http://ncsszi.hu/download.php?file_id=1528).

Kovács K., Kovács K. E. \& Nagy B. E. (2016): Intézményi hatások a hallgatók egészségtudatos magatartásában. In: Pusztai G., Ceglédi T. \& Bocsi V. (szerk.): Érték, amit az intézmény hozzáadott. Közelitések az intézményi hozzájárulás empirikus megragadásához. Nagyvárad-Debrecen: Partium Press, Új Mandátum Könyvkiadó.

Kovács K. \& Perényi Sz. (2014). In: Nagy Á. \& Székely L. (szerk.):Másodkézböl. Magyar Ifjúság 2012.Budapest, Kutatópont, 245-262. (Download: 2016.02.01.). (Web: http://kutatopont.hu/files/2012/02/Magyar_Ifjusag_2012_MASODKEZBOL.pdf). 
Lohaus, A., Vierhaus, M. \& Ball, J. (2009). Parentig styles and healthrelated behaviour in childhood and early adolescence: results of a longitudinal study. The Journal of Early Adolescence, 29,449-475.

McArdle, P., Wiegersma, A., Gilvarry, E. (2002). European adolescent substance use: the roles of family structure, function and gender. Addiction, 97, 329-336.

Németh Á. (2003). Nemi érés és szexuális magatartás. In Aszmann A. (szerk.): HBSC Iskoláskorú gyermekek egészség-magatartása. Országos Gyermekegészségügyi Intézet, Budapest, 77-85.

Németh Á. \& Költő A. (szerk, 2011). Serdülőkorú fiatalok egészsége és életmódja 2010. Budapest, Országos Gyermekegészségügyi Intézet. (Download: 2016.02.01.). (Web: http://www.ogyei.hu/anyagok/HBSC_2010.pdf).

Pate, R. R., Heath, G. W., Dowda, M, \& Trost, S. G. (1996). Associatins between physical activity and other health behaviors in a representative sample of US adolescents. American Journal of Public Health, 86,1577-1781.

Pikó B. (2005). Középiskolás fiatalok szabadidő-struktúrája, értékattitűdjei és egészségmagatartása. Szociológiai Szemle, 2, 88-99.

Pluhár Zs., Keresztes N. \& Pikó B. (2004). A rendszeres fizikai aktivitás és pszichoszomatikus tünetek kapcsolata általános iskolások körében. Sportorvosi szemle, 4,285-300.

Poortinga, W. (2006). Social relations or social capital? Individual and community health effects of bonding social capital. Social Science \& Medicine, 63, 255-270.

Rothspan, S. \& Read, S.J. (1996). Present versus time perspective and HIV risk among heterosexual college students. Health Psychology, 15, 131-134.

Sabo, D.F., Miller, K. E., Farell, M. P., Melnick, M. J. \& Barnes, G.M. (1999). High school athletic participation, sexual behavior and adolescent pregnancy: A regional study. Journal of AdolescentHealth, 25, 207-216.

Sebestyén E. (2003). Illegális szerek használata. In Aszmann A. (szerk.): HBSC Iskoláskorú gyermekek egészség-magatartása. Országos Gyermekegészségügyi Intézet, Budapest, 6176.

Steptoe A., Wardle J., Fuller R., Holte, A., Justo, J., Sanderman, R. \& Wichstrøm, L. (1997). Leisure-time physical exercise: prevalence, attitudinal correlates, and behavioral correlates among young Europeans from 21 countries. Preventive Medicine, 26, 845-854.

Susánszky É.\& Szántó Zs. (2002). Az egészségi állapot szempontjából veszélyeztetett fiatalok demográfiai és társadalmi jellemzői. In Szabó A. Bauer B. és Laki L. (szerk.): Ifjúság 2000. Tanulmányok I. Nemzeti Ifjúságkutató Intézet, Budapest, 154-165.

Waldfogel, J., Craigie, T. \& Brooks-Gunn, J. (2010). Fragile families and child well-being. Fall 20 (2),87-112. 